\title{
中心型早期肺癌に対する光線力学的治療の効果とその問題点 一内視鏡所見との関連を中心として一
}

\author{
島谷英明、奥仲哲弥、小中千守、酒井治正、 \\ 古川欣也、山本 豊、渋谷 洋、加藤治文 \\ 東京医科大学外科学教室 第一講座
}

\begin{abstract}
Efficacy of photodynamic therapy for centrally located early lung cancer - a corelation between bronchoscopic findings and theraputic effects -

Hideaki Shimatani, Tetsuya Okunaka, Chimori Konaka, Harumasa Sakai, Kinnya Furukawa, Yutaka Yamamoto, Hirosi Shibuya and Harubumi Kato

Department of 1st Surgery, Tokyo Medical College
\end{abstract}

Abstruct: We have performed photodynamic therapy (PDT) for early stage lung cancer cases since March 1980. In many cases, the result was satisfied, but some cases showed less tumor reduction as much as expected. So we investigate a correlation between the result of treatment and bronchoscopic findings.

Patients and Methods: Patients had histologically proven lung cancer and bronchoscopically estimated carcinoma in situ. The number of patients was 72 and that of lesions was 91. All lesions were photoirradiated using fiber optic bronchoscope. Photofrin II or $\mathrm{HpD}$ were given intravenously before radiation. The light sources were Argon-gye laser or Excimer-dye laser.

Results: Lesions that resulted complete remission (CR) were 69 and CR rate was $75.8 \%$. CR rate of lesins that diameters were $2 \mathrm{~cm}$ or more was obviously bad $(33.3 \%)$ in comparison with that of lesions less than $2 \mathrm{~cm}$ in diametr $(80 \%)$. CR rate of superficial appearences was $77.9 \%$, and that of nodular and polypoid type were 73.3 and $62.5 \%$ respectively. Lesions that the distal margins were visible using bronchoscopes showed good result (CR rate: $80.9 \%$ ), but the lesions that the distal margins were not visible resulted badly $(64.3 \%)$. Conclusion: The lesions with factors as follows

1. diameter of tumor was $2 \mathrm{~cm}$ or more.

2. distal margin is not visible bronchoscopically.

3. polypoid type in appearence.

showed less tumor reduction.

Lesions less than $1 \mathrm{~cm}$ or less in diameters, superficial appearences and the distal margins of those were visible showed very good reaction to PDT (CR rate: $91.3 \%$ ).

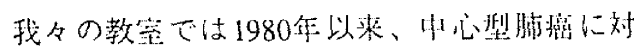

する呞所療法として気管支ファイバースコー

プを朋いた光線力学的治㓗法 (Photodynamic

Theraoy; PDT) を施行してきた。現在まで舁期
胡癌に対し鼠好な治搌結果が得られているが、 治㙩前の予澌に反し不䒧全な治療となった声 例も散見された。今回我々は、内視鏡所罗と 治療成綪の関要を検討を加え都些する。 
対象は1980年3月より1995年7月まで当科にて PDT を施行された中心型早期肺癌症例72例、91 病巣である。内、69病紧に完全治痛が得られ、 治瘾率は75.8\%。不完全治撚16病渠、完全治瘾 後再発は6病巣であった。内視鏡分類別では表 在型68病皇、結節型 15 病巣、Polypoid type 8 病

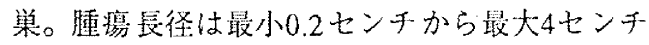
メートル、平均0.88センチメートルであった。

PDTの結果が不完全治瘾であった16病鉴につい てその原因を分類すると、腫㻛長径が2センチ 以上の病巣の内不完全治湓が10病采あり、治瘾 率は33.3\%であった。また腫演の存在または解 剖学的要因により腫湯末梢境界の確瑟が不可能

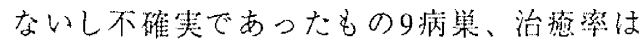
64.3\%。更に内視鏡分類上Polypoid typeのもの2 病鉴、治漟率62.5\%であった（Table 1)。これ らの要因について個別に検討を加えた。

\section{中心型早期肺癌 PDT 施行症例} 不完全治癒症例の検討

\begin{tabular}{|c|c|c|}
\hline 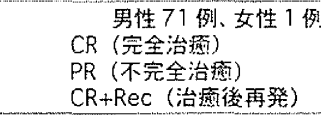 & \multicolumn{2}{|c|}{$\begin{array}{l}91 \text { 病果 } \\
; 69 \text { 病果 }(75.8 \%) \\
; 16 \text { 病果 } \\
; 6 \text { 病栔 }\end{array}$} \\
\hline $\begin{array}{l}\text { 表在型 } \\
\text { 結節型 } \\
\text { Polypoid type }\end{array}$ & \multicolumn{2}{|c|}{$\begin{array}{l}68 \text { 病菜 } \\
15 \text { 病躷 } \\
8 \text { 病菓 }\end{array}$} \\
\hline 不完全治汿の原因 & 病槥数 & 治贸率 \\
\hline 1. 腄㟫長径 $2 \mathrm{~cm}$ 以上 & 10 满策 & $33.3 \% *$ \\
\hline 2. 本梢確認不能 & 9 病䔩 & $64.3 \%$ * \\
\hline 3. 内視鏡分類 - Polypoid type & 2 病棵 & $62.5 \%$ * \\
\hline
\end{tabular}

Table 1

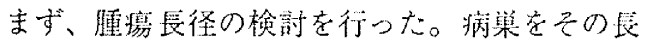
径により $0.5 \mathrm{~cm}$ 未满、 $0.5 \mathrm{~cm}$ 以上 $\mathrm{Icm}$ 未满、 $1 \mathrm{~cm}$ 以上 $2 \mathrm{~cm}$ 未満、 $2 \mathrm{~cm}$ 以上の 4 群に区分し、治療成 積を比較した結果、腫㹸长径が2センチ来满の 各群の治瘾染はいずれも80\%以上と良好であっ た。しかし長径が2センチ以上の碓の治揞染は 33.3\%であり、明らかに不良であった（Table2）。 次に気管支ファイバー下に腫溰末梢辺粨が確認 できた病巢と、末梢確䜑が不可能或いは不確実
であった病巣の治療成績を比較した。前者の治 癒率は $80.9 \%$ あり、後者の64.3\%と不良であっ た (Table 3)。

\begin{tabular}{|c|c|c|c|c|}
\hline \multicolumn{5}{|c|}{ 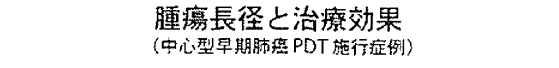 } \\
\hline 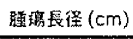 & 病然数 & 完全治速 (CR) & 不完全治症 (PR) & CR 復再発 \\
\hline$<0.5$ & 34 & $30(88.2 \%)^{\star}$ & 2 & 2 \\
\hline $0.5 \leqq<1.0$ & 32 & $26(81.3 \%)^{*}$ & 3 & 3 \\
\hline $1.0 \leqq<2.0$ & 10 & $8(80.0 \%)^{\star}$ & 1 & 1 \\
\hline \multirow[t]{2}{*}{$2.0 \leqq$} & 15 & $5(33.3 \%)^{\star}$ & 10 & 0 \\
\hline & 91 & $69(75.8 \%)^{*}$ & 16 & 6 \\
\hline
\end{tabular}

\section{腫瘍末梢側確認の可否と治療効果} (中心型早闑胡㾦 PDT施行症例)

\begin{tabular}{|c|c|c|c|c|}
\hline 末梢磪留 & 病辈数 & 完全治通 (CR\%) & 不完全治视 (PR\%) & CR 後再発 \\
\hline 可能 & 63 & $\begin{array}{r}51(80.9 \%)^{*} \\
(91.3 \%)^{* *}\end{array}$ & 7 & 5 \\
\hline 不可能 & 28 & $18(64.3 \%)^{\star}$ & 9 & 1 \\
\hline at & 91 & $69(75.8 \%)^{\star}$ & 16 & 6 \\
\hline
\end{tabular}

Table 3

更に内視鏡分類と治療成莧との閔係を検討した。

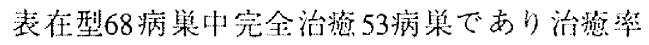
$77.9 \%$ 結節型の $73.3 \%$ 大大きな美は䍿められな かった。これに対し、Polypoid typeの治湆梦は 62.5\%とやや不良であった（Table 4）。

内視鏡分類と治療効果

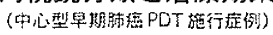

\begin{tabular}{|c|c|c|c|c|}
\hline 内现鍤分㩆 & 病柴数 & 完全治晟 (CR\%) & 不完全治豛 (PR\%) & CR 後再発 \\
\hline 結箱型 & 15 & $11(73.3 \%)^{*}$ & 2 & 2 \\
\hline 婊在型 & 68 & $\begin{array}{r}53(77.9 \%)^{\star} \\
(86.7 \%)^{*}\end{array}$ & 12 & 3 \\
\hline Polypoid & 8 & $5(62.5 \%)^{*}$ & 2 & 1 \\
\hline 計 & 91 & $69(75.8 \%)^{*}$ & 16 & 6 \\
\hline
\end{tabular}




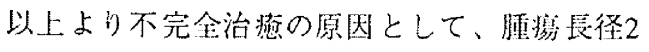
センチ以上、腫晹未梢の確潖不可能ないし不確 実、内視鏡分類上Polypoid typeである事の3つが 考えられた。以下に症例を旺示する。

症例1 未梢確認不能の症例を示す。Fig. 1 は PDT前の内視鏡像である。存B9-B10分岐部より B8人口部にかけて表在型の腫場を認め、B9及び B10は入日部で閉塞していた（左）。右に治療 後31日目の同部の内視鏡像を示す。B9,10は完 全に開口していたが、B10入口部付近に癌の残 存が䜑められた。

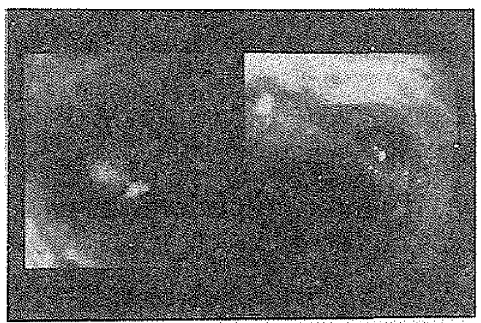

Fig.1

㫌例2 Polypoid typeの症例である。腫擅は有B6

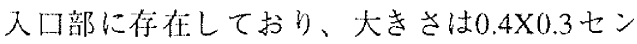
チ、スライド右側にボリープの茎が琶められた

(Fig. 2)。

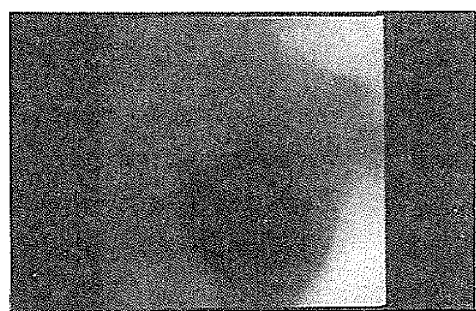

Fig.2

症例3 表在型の症例である。有B9-B10分岐部

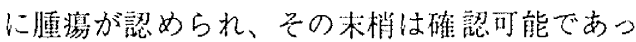
た。スライド不にPDT4週間後の内視鏡像を示 す。分岐部向かって左に、霾境の残存が認めら れた為、右下葉切除施行となった（Fig. 3)。
腫瘍残存部の組織像では、一部軟骨層を越える

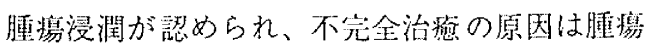
進達度評优の䛊りと考えられた。（Fig.4）

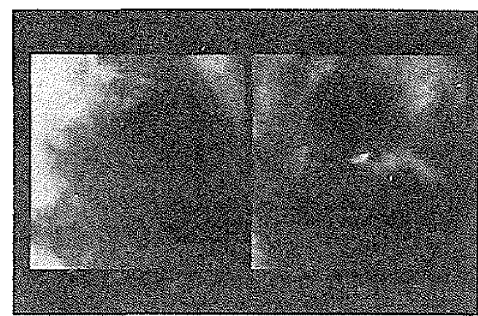

Fig.3

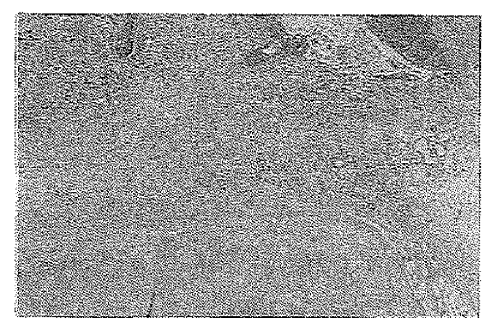

Fig.4

結語

中心型早期肺澏に対し行われたPDTの治摺結瑟 を㭘尌し、治游不成功の原因について考察した。

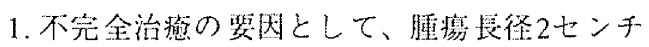

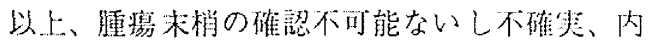
視鏡分類上Polypoid type、が若えられた。

2. 内視鏡分類で表在型と結節型の治愁率に明ら かな差は琶められなかった。

3. 長径1センチ以下の表在型で末梢側が父管支 ファイバースコープ下に確認可能な46病勧の治 痹摔を検傠した結果、91.3\%と極めて良好であっ た。 